\title{
A sürgősségi osztályon szédüléses panaszokkal megjelent betegek életminőségének vizsgálata
}

\author{
Maihoub Stefani dr. ${ }^{1}$. Molnár András dr. ${ }^{1}$ - Csikós András dr. ${ }^{2}$ \\ Kanizsai Péter dr. ${ }^{2}$. Tamás László dr. ${ }^{1}$ - Szirmai Ágnes dr. ${ }^{1}$
}

${ }^{1}$ Semmelweis Egyetem, Általános Orvostudományi Kar, Fül-Orr-Gégészeti és Fej-Nyaksebészeti Klinika, Budapest ${ }^{2}$ Semmelweis Egyetem, Sürgősségi Betegellátó Osztály, Budapest

Bevezetés: A szédülés gyakori panasz, amellyel a betegek felkeresik a sürgősségi osztályt. Emellett fontos tünet, hiszen kihívást jelent mind a diagnosztika, mind a terápia szempontjából, és nagy hatással lehet a betegek életminőségére. Célkitüzés: Kutatásunk célja annak vizsgálata, hogy mennyire befolyásolta a szédülés a betegek életminőségét a sürgősségi osztály elhagyását követően.

Módszer: A vizsgálat időtartama alatt 879, szédülést panaszoló beteg jelent meg a Semmelweis Egyetem sürgősségi osztályán. Részükre kérdőív került kiküldésre, amely tartalmazta a 'Dizziness Handicap Inventory' (DHI-) kérdőívet is. Megkeresésünkre 308 beteg (110 férfi, 198 nő; átlagéletkor: 61,8 \pm 12,31 SD) válaszolt, az általuk visszaküldött kérdőíveket részletesen elemeztük.

Eredmények: A leggyakoribb diagnózisok közé a benignus paroxysmalis positionalis vertigo, a centrális egyensúlyrendszeri eltérések és a szédülékenység tartoztak. Az elemzés alapján különbség volt látható a fizikális, a funkcionális és az emocionális pontszámok között. Kiemelendő, hogy a legmagasabb értékeket a fizikális csoportban regisztráltuk. A részletes otoneurológiai kivizsgáláson átesett betegek DHI-értékeit összevetettük azokéival, akik nem jártak ilyen vizsgálaton, a két csoport értékei között azonban nem volt szignifikáns különbség $(p=0,97)$. Emellett a DHI-érték emelkedése volt látható a végleges diagnózisig eltelt idő függvényében.

Következtetés: A végleges diagnózisig eltelt idő, illetve a megfelelő kivizsgálás hiánya jelentős hatással van a szédülő betegek életminőségére. Lényeges a kivizsgálás, a mielőbbi diagnózis és a részletes egyensúlyrendszeri vizsgálat szerepe, ugyanakkor az utóbbi indokolt esetben kell, hogy történjen.

Orv Hetil. 2021; 162(30): 1216-1221.

Kulcsszavak: szédülés, sürgősségi osztály, utánkövetés, ’Dizziness Handicap Inventory’ kérdőív, életminőség

\section{Assessment of the patients' quality of life visiting the emergency department with dizziness}

Introduction: Dizziness and vertigo are among the most common complaints in the emergency department. This may require interdisciplinary cooperation due to their complex presentation in the department and the effects on the patients' quality of life.

Objective: Our study aimed to assess the effect of an acute vertigo episode on the quality of life after patients' discharge from the emergency department.

Method: 879 patients examined at the Semmelweis University emergency department with vertigo and dizziness were included in the study. A questionnaire, including the Dizziness Handicap Inventory (DHI), was addressed to this population. We received 308 answered questionnaires back (110 males, 198 females; mean age 61.8 years \pm 12.31 SD), which were further analyzed.

Results: The most frequent diagnoses were benign paroxysmal positional vertigo, central lesions and dizziness. According to the analysis of the DHI questionnaire, a difference between physical, functional and emotional scores was shown, whereas the highest scores were registered in the physical group. The DHI questionnaire scores of patients undergoing a neurotological examination and those who did not were further compared, whereas no significant statistical difference was indicated $(\mathrm{p}=0.97)$. In addition, an increase in DHI scores was seen depending on the time elapse for the definitive diagnosis. 
Conclusion: The absence of adequate examination and a late diagnosis of the dizziness cause have a significant impact on the quality of life of patients. Therefore, substantial investigation, early diagnosis, and detailed vestibular examination are essential, but the latter should take place in justified cases.

Keywords: vertigo, emergency department, follow-up, Dizziness Handicap Inventory questionnaire, quality of life

Maihoub S, Molnár A, Csikós A, Kanizsai P, Tamás L, Szirmai Á. [Assessment of the patients' quality of life visiting the emergency department with dizziness]. Orv Hetil. 2021; 162(30): 1216-1221.

(Beérkezett: 2021. január 2.; elfogadva: 2021. február 2.)

\section{Rövidítések}

$\mathrm{BPPV}=$ benignus paroxysmalis positionalis vertigo; $\mathrm{CT}=$ (computed tomography) számítógépes tomográfia; DHI = (Dizziness Handicap Inventory) szédülésterheltségi skála; HINTS $+=$ (head impulse test, nystagmus, test of skew deviation, acute hearing loss) fejimpulzusteszt, a nystagmus vizsgálata, a vertikális szemtengely-deviáció vizsgálata, akut halláscsökkenés; $\mathrm{MR}=$ (magnetic resonance $)$ mágneses magrezonancia; $\mathrm{SD}=$ standard deviáció

A sürgősségi osztályon megjelenő betegek 3,5-11\%-a panaszol szédülést, a háttérben álló betegség diagnosztikája és a megfelelő kezelés pedig problémákat vethet fel $[1,2]$. A panaszok hátterében perifériás vagy centrális vestibularis és/vagy extravestibularis eredetú eltérések állhatnak. A leggyakoribb ok a perifériás, belsőfül-eredetû́ eltérés, amely többnyire jóindulatú, így a kezelés a legtöbb esetben nem sürgôs, de feltétlenül szükséges. Ezen elváltozások közé tartozik például a neuronitis vestibularis, a benignus paroxysmalis positionalis vertigo (BPPV), a Ménière-betegség, a labyrinthitis vagy a bilateralis vestibulopathia. Bár a perifériás vestibularis eltérésben szenvedő betegek nagy része 24 órán belül emittálható, a későbbi részletes kivizsgálás lényeges, amely azonban gyakran nem történik meg. Ugyanakkor centrális vestibularis eltérés esetén sürgős ellátás lehet szükséges, mert a háttérben állhat például stroke vagy tranziens ischaemiás attak [3], de az ok lehet például sclerosis multiplex is. Az extravestibularis okok közé tartoznak a belgyógyászati, kardiológiai eltérések, valamint a pszichiátriai vagy reumatológiai rendellenességek is.

A beteg vizsgálata során az orvos célja a belsófül-betegségek elkülönítése a centrális okoktól, például a stroke-tól [4], ennek megfelelően a diagnosztika javítása kiemelten fontos kérdés. A sürgősségi osztályon a vizsgálati metodikák közé tartoznak a különböző képalkotó eljárások, a legtöbb esetben azonban sem a CT-, sem az MR-vizsgálat nem tud pontos diagnózist adni, a vizsgálatok eredménye sok esetben negatív lehet, még azokban az esetekben is, amikor a háttérben centrális ok áll [5]. Varga és mtsai kutatásukban megállapították, hogy a szédülő betegek a sürgősségi beteganyag közel 3\%-át teszik ki. Rámutattak, hogy koponya-CT az esetek 44\%-ában készült, a szédülés okát azonban csak 2 esetben tudta kimutatni, utalva az ágy melletti vizsgálatok fontosságára [6]. Az említett okok miatt lényeges az ágy melletti vizsgálatok alkalmazása és a diagnosztika lehetőség szerinti pontosítása [7]. Mint ágy melletti vizsgálat, a HINTS+ (head impulse test, nystagmus, test of skew deviation, acute hearing loss) létjogosultsága egyértelmú. Az oculomotoros rendszer ágy melletti vizsgálata az első 48 órában a stroke tekintetében $100 \%$-os szenzitivitást mutat, így megbízhatóbb, mint a diffúziógátolt MR-vizsgálat [8]. Korábbi tanulmányok alapján általánosnak mondható jelenség, hogy a perifériás vestibularis eltéréseket nem diagnosztizálják és kezelik megfelelően a sürgősségi osztályon, a téves diagnózisok aránya a nemzetközi statisztikák alapján $74-81 \%[9,10]$. A sürgősségi ellátás során vizsgált betegek gyakran panaszkodnak epizódokban (visszatérően) megjelenő szédülésről, amely rontja a betegek mindennapi életvitelét és az életminőségüket [11]. Gyakori betegségek - mint például a BPPV és a neuronitis vestibularis - differenciáldiagnózisa sokszor nehézségekbe ütközik [9]. A BPPV élettartam-prevalenciája $2 \%$ körül van [12], és lényeges, hogy megfelelő terápiával gyógyítható, ugyanakkor a szédüléses epizódok sok esetben ismétlődhetnek. Az első tüneteket követó l évben a kiújuló BPPV aránya $20 \%$, míg 5 év múlva 50\% körül van [13]. Ezzel szemben például a Ménière-betegség definitíven nem gyógyítható, ezért magasabb élettartam-prevalenciát mutat, így kezelése az életminőség szempontjából nagy jelentőséggel bír [14]. Ezért annak ellenére, hogy nem életveszélyes elváltozásokról van szó, a diagnosztikára és a kezelésre a perifériás eltérések esetén is fontos hangsúlyt fektetni. Emellett a szédülést panaszoló betegek $\mathrm{kb}$. fele szenved valamilyen pszichés eltérésben a nem vagy nem megfelelően diagnosztizált és kezelt betegség miatt [15]. A centrális vestibularis rendellenességek felismerése elengedhetetlen, hiszen hátterükben életveszélyes elváltozás is állhat. Centrális vestibularis eltérések esetén a leggyakrabban érrendszeri ok igazolódik [16], és mind az akutan jelentkező, mind a krónikusan fennálló szédülés esetén létezik bizonyítékokon alapuló kezelés [17].

A centrális és a perifériás vestibularis eltérések egyaránt hatással lehetnek a betegek életminőségére és életvitelére, ezért fontosak az olyan kutatások, amelyek az ezzel kapcsolatos beteganyagot és a lehetséges rehabilitációt 
vizsgálják. Kutatásunkban a sürgősségi osztályon megjelent, szédülést panaszoló betegek kivizsgálását és a szédülés életminőségre kifejtett hatását értékeljük.

\section{Módszer}

\section{Betegcsoport}

Kutatásunkban a Semmelweis Egyetem Sürgősségi Betegellátó Osztályán két és fél év alatt megjelent, szédülést panaszoló betegek adatait elemeztük. Ebben az időszakban 879 beteg jelent meg szédülés miatt az osztályon. A tanulmány a Semmelweis Egyetem Regionális, Intézményi Tudományos és Kutatásetikai Bizottságának engedélyével készült: 28/2018.

A vizsgálatba bevont betegekhez a tünetekre vonatkozó kérdőívet [18], valamint a 'Dizziness Handicap Inventory' (DHI-) kérdő́ivet [19] juttattuk el postai úton, magyar nyelven. A kérdőívet megkapó betegek közül 308 válaszolt, az ő adataikat további elemzésnek vetettük alá.

\section{Kérdőív}

A kérdőív első része kérdéseket tartalmazott a szédülés jellegzetességeirôl, így annak időtartamáról, jellegéról és a társuló egyéb tünetekről (hányinger, hányás, halláskárosodás, fülzúgás, látászavar, ájulás, fejfájás). Ezt követően a sürgősségi osztály dokumentációjában szereplő diagnózisra kérdeztünk rá, valamint arra, hogy milyen tájékoztatást kaptak a sürgősségi osztályról történő távozás előtt. A kérdőív utolsó részében a későbbi kivizsgálások eredményére kérdeztünk rá, valamint csatoltuk a DHI-kérdőívet [19]. A DHI-kérdőív széles körben használt eszköz a szédülésben és egyensúlyproblémában szenvedő betegeknél, segítségével megállapítható a szédülés által kiváltott életminőség-romlás mértéke. A kér-

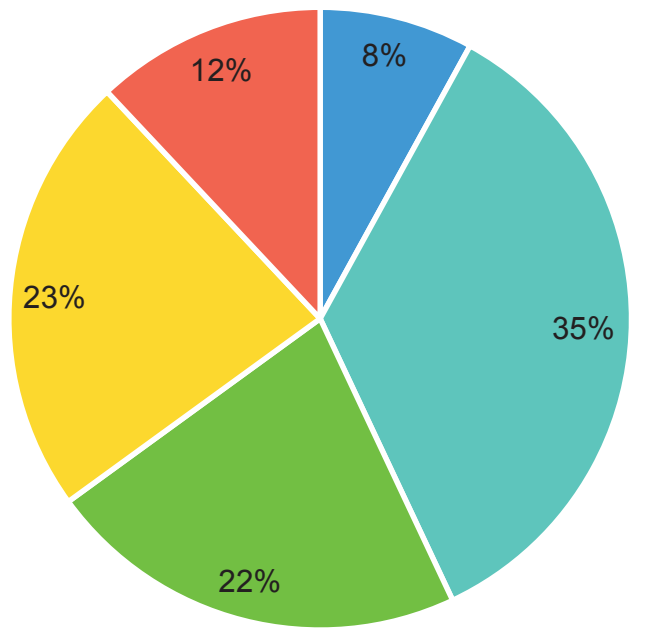

Percek Másodpercek @Órák Pár napja állandó

1. ábra $\quad$ A szédüléses epizódok időtartama a betegek válaszai alapján dőívet korábban számos tanulmányban használták, kiegészítve az egyensúlyrendszeri vizsgálatok eredményeivel [19]. A DHI összesen 25 kérdést tartalmaz; a válaszok alapján maximálisan 100 pont érhető el, és a pontszám értékével párhuzamosan emelkedik az életminőség-romlás mértéke. A kérdőív különböző aspektusokat vizsgál, így tartalmaz 7 fizikális, 9 funkcionális és 9 emocionális kérdést; ezek pontszámainak összegéből határozható meg a teljes DHI-pontszám. Értékelése a következő: „igen” válasz esetén 4 , „néha” esetén 2 , „nem” esetén 0 pont jár az adott kérdésre. A 16-34 pont enyhe, a 36-52 pont közepes, az 54 feletti pontszám súlyos életminőség-romlást jelez [19]. A DHI validitását igazolta, hogy magasabb pontszám esetén gyakoribb szédüléses epizódok és súlyosabb funkcionális károsodás állt a háttérben $[20,21]$.

\section{Statisztikai elemzés}

A statisztikai elemzést IBM SPSS V24 szoftverrel (IBM Corporation, Armonk, NY, Amerikai Egyesült Államok) végeztük. Mivel a vizsgált paraméterek nem mutattak normális eloszlást (Shapiro-Wilk-teszt), nemparametrikus tesztet (Mann-Whitney U-teszt) használtunk. A szignifikanciaszintet $\mathrm{p}<0,05$-ként határoztuk meg.

\section{Eredmények}

A kitöltött kérdőívet 308 beteg (110 férfi, 198 nő, átlagéletkor 61,8 év $\pm 12,31$ SD) juttatta vissza. A kérdőívet visszaküldő betegek a sürgősségi vizsgálat alapján a következő betegségekben szenvedtek: Ménière-betegség $(\mathrm{n}=4), \operatorname{BPPV}(\mathrm{n}=51)$, neuronitis vestibularis $(\mathrm{n}=10)$, egyéb perifériás vestibularis elváltozás $(\mathrm{n}=32)$, centrális vestibularis eltérés $(n=71)$, szédülékenység $(n=64)$, vestibularis migrén $(n=2)$, és 74 beteg esetén nem született végleges diagnózis. Ennek megfelelően a diagnózisok megoszlása a következőképpen alakult: perifériás vestibularis laesiók 37\%-ban, centrális vestibularis eltérések 29,5\%-ban jelentek meg, és 23,5\%-ban nem született végleges diagnózis. Ahogy az 1. ábrán látható, az epizódok a leggyakrabban másodpercekig tartottak, ezt követte gyakoriságban a napokig tartó szédülés. A szédüléses epizódok időtartama jellegzetes az adott kórképre. A másodpercekig tartó vertigo gyakran látható BPPV-ben, a legalább 20 percig, de sok esetben órákig tartó szédülés pedig Ménière-betegségben fordul elő. A több napig tartó szédülés az akut vestibularis szindróma jellegzetessége, míg az állandó egyensúlyzavar általában a centrális laesiókra jellemző. A betegek a leggyakrabban másodpercekig tartó szédülést panaszoltak, ez utal a BPPV gyakori előfordulására. Ezt követte az órákig és a több napig tartó szédülés, ami lényeges, hiszen a tartós epizódok nagy jelentőséggel bírnak a betegek életminősége szempontjából.

A szédülés mellett a betegek a legtöbb esetben kísérő tüneteket tapasztaltak, ezek közül a leggyakoribb a hány- 
1. táblázat |A szédülést kísérő tünetek

\begin{tabular}{lc}
\hline Kísérő tünetek & Betegek $(\%)$ \\
\hline Hányinger & 27 \\
Fejfájás & 21 \\
Fülzúgás & 17 \\
Hányás & 17 \\
Hallásromlás & 11 \\
Eszméletvesztés & 7 \\
\hline
\end{tabular}

inger volt, amely gyakori vegetatív kísérő tünet (1. táblázat). Az összes kísérő tünet hatással lehet az életminőségre, de a hányinger és a hányás hatása kiemelendő, mert ezek a tünetek nagyon erős hatást gyakorolnak a mindennapi életvitelre.

A DHI-kérdőívek eredménye alapján statisztikai elemzést végeztünk. A betegeket két csoportra osztottuk aszerint, hogy történt-e tervezetten otoneurológiai kivizsgálás vagy sem. Ahogy a 2. ábrán látható, a két csoport teljes DHI-pontértékeit statisztikai elemzés segítségével összevetve nem mutatkozott szignifikáns különbség $(\mathrm{p}=0,97)$. Ez az eredmény azzal magyarázható, hogy az otoneurológiai vizsgálat sokszor nem indokolt esetekben történt. Azokban az esetekben, amikor a szédülés hátterében például belgyógyászati, reumatológiai, valamint kardiológiai eltérések állnak, kisebb a komplex egyensúlyrendszeri kivizsgálás jelentősége. Ezért fordulhatott elő, hogy a két csoport DHI-értékei nem különböztek lényegesen, hiszen indokolt esetekben a részletes kivizsgálás hiányzott. A dokumentáció alapján indokolt esetekben (BPPV: 14, neuronitis vestibularis: 3, Ménièrebetegség: 1) otoneurológiai vizsgálat az esetek

A teljes DHI-érték alakulása az otoneurológiai kivizsgálás függvényében

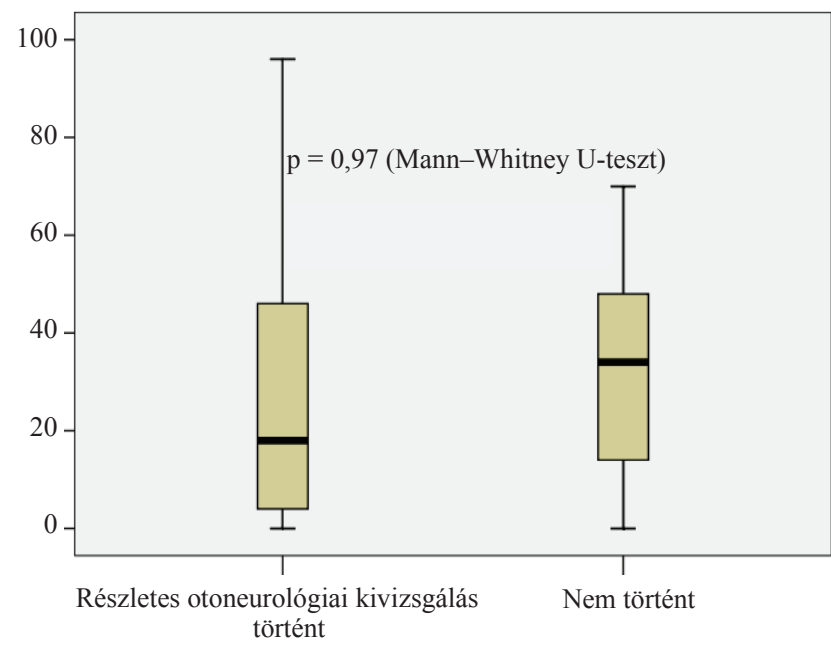

2. ábra

A teljes DHI-pontszám és az otoneurológiai kivizsgálás közötti összefüggés

DHI = 'Dizziness Handicap Inventory' kérdőív
2. táblázat A teljes DHI-érték alakulása a diagnózisig eltelt idő függvényében

\begin{tabular}{lcc}
\hline A diagnózisig eltelt időtartam & Átlag \pm SD & $\begin{array}{c}\text { p-érték } \\
\text { (Mann-Whitney U-teszt) }\end{array}$ \\
\hline Napok & $18 \pm 2$ & $\mathrm{p}=0,01^{*}$ \\
\hline Hetek & $55 \pm 33$ & $\mathrm{p}=0,2$ \\
\hline Hónapok & $44,7 \pm 3$ & $\mathrm{p}=0,03$ * \\
\hline Egy év & $95 \pm 5$ & \\
\hline
\end{tabular}

* szignifikáns különbség

mindössze 23,5\%-ában és legalább általános fül-orr-gégészeti vizsgálat is csupán az esetek 35,3\%-ában történt.

Elemeztük az életminőség alakulását annak függvényében, hogy az első tünetek megjelenéséhez viszonyítva mennyi idő alatt történt meg a megfelelő kivizsgálás és a diagnózis felállítása. Összevetve a betegek teljes DHI-értékeit, ahogy a 2. táblázatban látható, statisztikailag szignifikáns különbség mutatkozott a napok és a hetek között, ami a később megszületett diagnózis esetén magasabb teljes DHI-pontszámot, rosszabb életminőséget jelent. A hónapok és egy év intervallum között is jelentős különbség volt, bár a hetek és a hónapok között nem detektáltunk különbséget.

A DHI-alkategóriákat elemezve az volt látható, hogy a szédülés a fizikális pontszámra volt a legnagyobb hatással. A boxplotok alapján (3. ábra) különbség volt látható a fizikális, a funkcionális és az emocionális pontszámok között, és a legmagasabb értékeket a fizikális csoportban regisztráltuk. A statisztikai elemzés alapján szignifikáns különbség volt kimutatható a fizikális és a funkcionális

Fizikális, funkcionális és emocionális eredmények

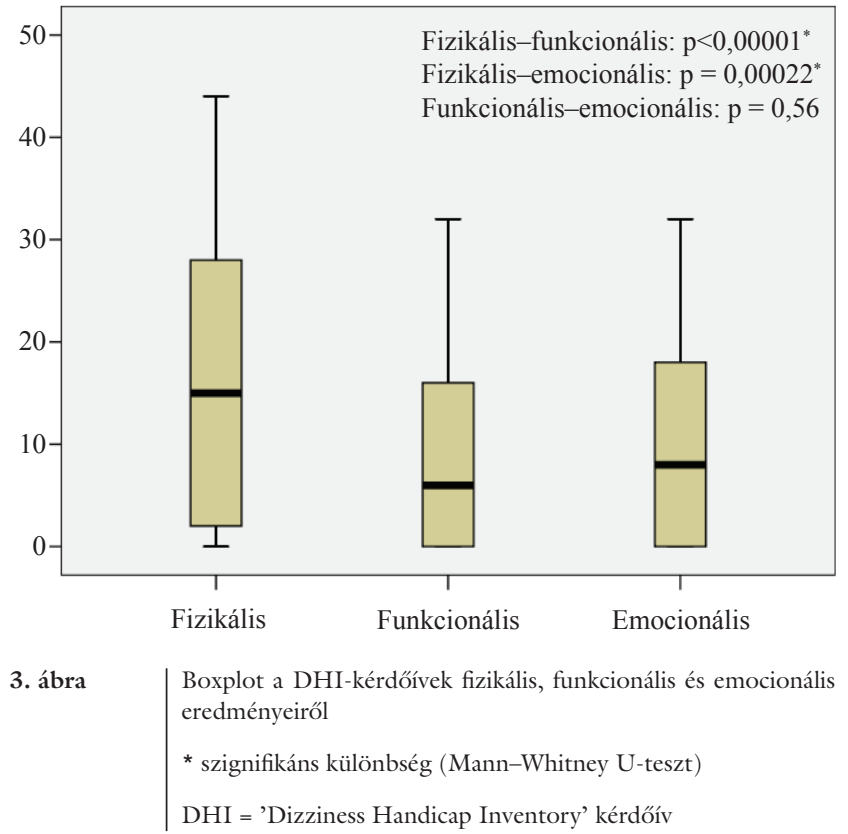


értékek között ( $\mathrm{p}<0,00001)$, a fizikális és az emocionális alcsoportok ( $\mathrm{p}=0,00022)$ között, azonban a funkcionális és az emocionális pontszámok között nem volt különbség $(\mathrm{p}=0,56)$. A fizikális pontszám kategóriájában található kérdések közé tartoznak olyan mindennapi tevékenységek, mint például az adott irányba tekintés, a séta vagy az ágyban történő átfordulás.

\section{Megbeszélés}

Az akut szédülés olyan állapot, amely jelentősen befolyásolja a betegek egészségi állapotát $[20,22]$, így az ezzel kapcsolatos ellátás az egészségügy értékelésének indikátora lehet. A betegek életminősége fontos információt adhat a diagnosztika és a terápia sikerességéról [23]. A DHIkérdőív pedig fontos eszköz lehet ennek felmérésében.

A jelen kutatás célja a szédülő betegek életminőségének vizsgálata volt, a sürgősségi osztály elhagyását követően. Megállapítottuk, hogy akár egy szédüléses epizód is nagy hatással lehet a betegek életminőségére. A betegek sok esetben 30 vagy ennél magasabb pontszámot értek el a DHI-kérdőív alapján [19], 16 pontnál magasabb érték esetén pedig a további kivizsgálás elengedhetetlen. Ezen elsősorban az otoneurológiai vizsgálatot értjük, de lényeges, hogy a kivizsgálás csak indokolt esetben lesz eredményes. Ennek megfelelően a nem belsőfül-eredetű szédülések esetén nem várható jelentős életminőség-javulás az otoneurológiai vizsgálatot követően. Ennek eldöntéséhez alkalmazható Szirmai módszere, aki az otoneurológiai vizsgálatra szoruló betegek kiválasztására 6 pontból álló kérdőívet javasol [24].

A vizsgált 308 beteg közül az összes esetben megfigyelhető volt a fizikális pontszám emelkedése, ami utal arra, hogy tüneteik következtében a betegek gátoltak a mindennapi feladatok elvégzésében, és ennek hatása lehet az emocionális értékekre is. Annak ellenére, hogy a fizikális alcsoport a kérdőív többi részéhez képest kevesebb kérdést tartalmaz, a betegek a legmagasabb pontszámot ebben a kategóriában érték el. A kérdőívet korábbi kutatásokban is alkalmazták. Fielder és mtsai megállapították, hogy a fizikális pontszám mindkét nem esetén szignifikánsan magasabb értéket adott, mint a kérdőív által vizsgált többi aspektus, ami a saját kutatásunkban hasonlóképpen alakult [25].

Eredményeink alapján az emocionális állapot szintén érintett volt, aminek hátterében a szédüléssel kapcsolatos negatív érzések, a napi feladatok elvégzésétől való félelem, a másoktól való függőség érzése és végső soron a kialakuló szorongás és depresszió áll. Yuan és mtsai hasonló következtetésre jutottak: eredményeik alapján a vestibularis rendellenességben szenvedők pszichológiai distresszt mutatnak, ideértve a depresszió és a szorongás társulását [26]. Lahmann a tanulmányában azt hangsúlyozza, hogy a szédülő populáció csaknem fele szenved valamilyen pszichológiai vagy pszichiátriai eltéréstől [15]. Emellett természetesen a funkcionális pontszám is fontos, hiszen ennek értéke utalhat arra, hogy a minden- napi tevékenységek elvégzése, a szociális kapcsolatok károsodhatnak a betegek állapota következtében.

A kérdőívek elemzése alapján megfigyelhető volt, hogy a diagnózis késlekedésével párhuzamosan emelkedett az életminőség-romlás mértéke, ezért lényeges a kivizsgálás lehetőség szerint mihamarabbi megkezdése. Emellett felmértük a szédülést kísérő különböző tüneteket, melyek közül a fejfájás és a vegetatív tünetek voltak a leghangsúlyosabbak. Ez azért lényeges, mert egy korábbi tanulmány rámutatott, hogy a fejfájás, illetve a vegetatív tünetek megjelenése szignifikánsan negatív irányban befolyásolja a szédüléses rohamok megélését. Ezért a terápia során ezen panaszok kezelése is fontos szempont [27].

Az életminőség-romlás elkerülése érdekében hangsúlyozzuk tehát a megfelelő kivizsgálás és a mielőbbi adekvát terápia fontosságát. A vizsgált populáció alapján látható volt, hogy nem minden esetben történt meg a megfelelő kivizsgálás, illetve sok esetben nem megfelelő vizsgálatok történtek. Erre utal, hogy 24\%-ban nem született végleges diagnózis, a későbbi kivizsgálás eredményeként sem. Összevetve a későbbi részletes kivizsgálás eredményét a sürgősségi osztályon felállított diagnózissal, egyezés csupán 25,8\%-ban volt megfigyelhető, ugyanakkor ezekben az esetekben kisebb életminőségromlást észleltünk, mint azoknál, akiknél végleges diagnózis nem született.

\section{Következtetés}

A szédülő betegek állapotának felmérésében az önkitöltő kérdőívek fontos szerepet játszanak, erre a leggyakrabban a DHI-kérdőívet alkalmazzák a gyakorlatban. A DHI-eredmények alapján a szédülést panaszoló betegeknél életminőség-romlás volt megfigyelhető. Annak érdekében, hogy ezt javíthassuk, megfelelő kivizsgálásra és kezelésre van szükség. Amennyiben perifériás vestibularis eltérés lehetősége merül fel, otoneurológiai kivizsgálás elvégzése indokolt. Azokban az esetekben, amikor a DHI-összpontszám értéke meghaladja a 16-ot, a további kivizsgálás mindenképp javasolt, tehát még enyhe életminőség-romlás esetén is.

Anyagi támogatás: A közlemény megírása, illetve a kapcsolódó munka anyagi támogatásban nem részesült.

Szerzői munkamegosztás: M. S.: Adatgyüjtés, a kérdőívek elemzése, a cikk megírása. M. A.: Adatgyüjtés, statisztikai elemzés, nyelvi korrekció. Sz. Á.: Témavezető, a beteganyag biztosítása, a kutatás folyamatos szakmai felügyelete és szupervíziója, kritikai véleményezés. Cs. A., K. P.: A sürgösségi betegdokumentáció rendelkezésre bocsátása, kritikai megjegyzések. T. L.: Intézményvezető, kritikai véleményezés. A cikk végleges változatát az összes szerző elolvasta és jóváhagyta.

Érdekeltségek: A szerzőknek nincsenek érdekeltségeik. 


\section{Irodalom}

[1] Crespi V. Dizziness and vertigo: an epidemiological survey and patient management in the emergency room. Neurol Sci. 2004; 25(Suppl 1): S24-S25.

[2] Lammers, W, Folmer W, Van Lieshout EM, et al. Demographic analysis of emergency department patients at the Ruijin Hospital, Shanghai. Emerg Med Int. 2011; 2011: 748274.

[3] Edlow JA. Diagnosing patients with acute-onset persistent dizziness. Ann Emerg Med. 2018; 71: 625-631.

[4] Pope JV, Edlow JA. Avoiding misdiagnosis in patients with neurological emergencies. Emerg Med Int. 2012; 2012: 949275.

[5] Saber Tehrani AS, Kattah JC, Kerber KA, et al. Diagnosing stroke in acute dizziness and vertigo: pitfalls and pearls. Stroke 2018; 49: 788-795

[6] Varga C, Nagy F, Drubits K. Analysis of the data of patients presenting for emergency treatment with vertigo. [A sürgősségi ellátásban szédüléssel jelentkező betegek adatainak elemzése.] Ideggyógy Szle. 2014; 67: 193-200. [Hungarian]

[7] Delaney KA. Bedside diagnosis of vertigo: value of the history and neurological examination. Acad Emerg Med. 2003; 10 1388-1395.

[8] Tamás TL, Garai T, Tompos T, et al. Vertigo in the emergency department: new bedside tests. [Szédülés vizsgálata a sürgősségi osztályon: új, ágy melletti diagnosztikai eljárások.] Orv Hetil. 2016; 157: 403-409. [Hungarian]

[9] Kerber KA, Morgenstern LB, Meurer WJ, et al. Nystagmus assessments documented by emergency physicians in acute dizziness presentations: a target for decision support? Acad Emerg Med. 2011; 18: 619-626.

[10] Royl G, Ploner CJ, Leithner C. Dizziness in the emergency room: diagnoses and misdiagnoses. Eur Neurol. 2011; 66: 256263.

[11] Walther LE. Current diagnostic procedures for diagnosing vertigo and dizziness. GMS Curr Top Otorhinolaryngol Head Neck Surg. 2017; 16: Doc02. Doi: 10.3205/cto000141.

[12] von Brevern M, Radtke A, Lezius F, et al. Epidemiology of benign paroxysmal positional vertigo: a population based study. J Neurol Neurosurg Psychiatry 2007; 78: 710-715.

[13] Rhim GI. Serum vitamin D and recurrent benign paroxysmal positional vertigo. Laryngoscope Investig Otolaryngol. 2016; 1: $150-153$.

[14] Molnár A, Maihoub S, Tamás L, et al. Conservative treatment possibilities of Ménière disease, involving vertigo diaries. Ear Nose Throat J. 2019: 145561319881838.

[15] Lahmann C, Henningsen P, Brandt T, et al. Psychiatric comorbidity and psychosocial impairment among patients with vertigo and dizziness. J Neurol Neurosurg Psychiatry 2015; 86: 302308 .
[16] Kerber KA, Meurer WJ, West BT, et al. Dizziness presentations in U.S. emergency departments, 1995-2004. Acad Emerg Med. 2008; 15: 744-750.

[17] Jauch EC, Saver JL, Adams HP Jr, et al. Guidelines for the early management of patients with acute ischemic stroke: a guideline for healthcare professionals from the American Heart Association/American Stroke Association. Stroke 2013; 44: 870-947.

[18] Maihoub S, Molnár A, Csikós A, et al. What happens to vertiginous population after emission from the emergency department? [Mi történik a szédülő beteggel a sürgősségi osztály elhagyása után?] Ideggyógy Szle. 2020; 73: 241-247. [Hungarian]

[19] Jacobson GP, Newman CW. The development of the Dizziness Handicap Inventory. Arch Otolaryngol Head Neck Surg. 1990; 116: 424-427.

[20] Whitney SL, Wrisley DM, Brown KE, et al. Is perception of handicap related to functional performance in persons with vestibular dysfunction? Otol Neurotol. 2004; 25: 139-143.

[21] Perez N, Garmendia I, García-Granero M, et al. Factor analysis and correlation between Dizziness Handicap Inventory and Dizziness Characteristics and Impact on Quality of Life scales. Acta Otolaryngol Suppl. 2001; 545: 145-154.

[22] Yardley L, Putman J. Quantitative analysis of factors contributing to handicap and distress in vertiginous patients: a questionnaire study. Clin Otolaryngol Allied Sci. 1992; 17: 231-236.

[23] Nishino LK, Granato L, Herrerias de Campos CA. Quality of life questionnaire application in patients before and after vestibular rehabilitation. Int Arch Otorhinolaryngol. 2008; 12: 517-522.

[24] Szirmai Á. Vertigo in everyday practice. [Szédülés a mindennapi gyakorlatban.] Fül-Orr-Gégegyógyászat 2011; 67: 201-207. [Hungarian]

[25] Fielder H, Denholm SW, Lyons RA, et al. Measurement of health status in patients with vertigo. Clin Otolaryngol Allied Sci. 1996; 21: 124-126.

[26] Yuan Q, Yu L, Shi D, et al. Anxiety and depression among patients with different types of vestibular peripheral vertigo. Medicine (Baltimore) 2015; 94: e453.

[27] Molnár A, Maihoub S, Fent Z, et al. Typical characteristics of the symptoms of patients suffering from Ménière's disease and the multidisciplinary approach. [A Ménière-betegség tüneteinek jellegzetességei és a multidiszciplináris megközelítés.] Orv Hetil. 2019; 160: 1915-1920. [Hungarian]

(Molnár András dr., Budapest, Szigony u. 36., 1083 e-mail: andrasm94@gmail.com)

A cikk a Creative Commons Attribution 4.0 International License (https://creativecommons.org/licenses/by/4.0/) feltételei szerint publikált Open Access közlemény, melynek szellemében a cikk bármilyen médiumban szabadon felhasználható, megosztható és újraközölhető, feltéve, hogy az eredeti szerző és a közlés helye, illetve a CC License linkje és az esetlegesen végrehajtott módosítások feltüntetésre kerülnek. (SID_1) 